\title{
More politicians, more corruption: evidence from Swedish municipalities
}

\author{
Andreas Bergh $^{1,2}$ (D) Günther Fink $^{3} \cdot$ Richard Öhrvall $^{4,5}$
}

Received: 30 June 2016/ Accepted: 15 May 2017/Published online: 25 May 2017

(C) The Author(s) 2017. This article is an open access publication

\begin{abstract}
In the literature on political economy and public choice, it is typically assumed that government size correlates positively with public corruption. The empirical literature, however, is inconclusive, owing to both measurement problems and endogeneity. This paper creates a corruption index based on original data from a survey covering top politicians and civil servants in all Swedish municipalities. The effect of more politicians on corruption problems is analyzed using discontinuities in the required minimum size of local councils. Despite the fact that Sweden consistently has been ranked among the least corrupt countries in the world, the survey suggest that non-trivial corruption problems are present in Sweden. Municipalities with more local council seats have more reported corruption problems, and the regression discontinuity design suggests that the effect is causal.
\end{abstract}

Keywords Corruption - Government size · Institutions · Local government · Political economy $\cdot$ Sweden

Electronic supplementary material The online version of this article (doi:10.1007/s11127-017-0458-4) contains supplementary material, which is available to authorized users.

Andreas Bergh

Andreas.bergh@ifn.se

Günther Fink

gfink@hsph.harvard.edu

Richard Öhrvall

richard.ohrvall@ifn.se

1 Department of Economics, Lund University, Box 7082, S-220 07 Lund, Sweden

2 Research Institute of Industrial Economics (IFN), Grevgatan 34 - 2 fl, Box 55665, SE-102 15 Stockholm, Sweden

3 Harvard School of Public Health, 665 Huntington Avenue, Boston, MA 02115, USA

4 Department of Management and Engineering, Linköping University, SE-581 38 Linköping, Sweden

5 Research Institute of Industrial Economics (IFN), P.O. Box 55665, SE-102 15 Stockholm, Sweden 


\section{Introduction}

What is the causal effect of government size on political corruption? A large number of papers have examined the relationship, but no consensus has emerged (Holcombe and Boudreaux 2015; Kotera et al. 2012; Fan et al. 2009; Gerring and Thacker 2005; Fisman and Gatti 2002; Goel and Nelson 1998). The contradictory results found in the literature likely can be attributed to at least three factors: first, differences in identification strategies chosen to overcome the inherent endogeneity of government size (suggesting that countries with less corruption may be more willing or able to increase the size of government); second, the considerable heterogeneity in the measures of government size used; and, third, the difficulties associated with measuring corruption.

This paper contributes to the relevant literature by using constitutional discontinuities in the required number of seats in Sweden's 290 local councils to estimate the causal effect of council size on corruption. A measure of corruption is created using a detailed survey developed in 2007 and administered to local politicians and civil servants in 2008. Using both the ordinary least squares (OLS) method, an instrumental variable (IV) approach and a regression discontinuity design (RDD), our results suggest that increasing the number of seats in local councils leads to more corruption problems.

The corruption survey used has several advantages compared to traditional measures of corruption. First, with the objective of measuring corruption as "inappropriate use of common power and authority for purposes of individual or group gain at common expense" (Warren 2004, p. 332), top politicians and officials in all Swedish municipalities were asked to report (without revealing their identities) any corrupt behavior observed in the community in the form of bribe offers personally received and corrupt behaviors observed among fellow civil servants or politicians. The survey thereby aimed to capture corruption in a broader sense than in many other studies, including in-kind transfers and petty corruption. It also included questions regarding both perceptions and experiences of corruption, as well as opportunities to act corruptly. Second, the same survey instrument was used for all Swedish municipalities. Hence, we have a consistent measurement while still having 290 different units to analyze. Third, by targeting both politicians and civil servants, the survey was completed by people likely to know if their municipalities were plagued by corruption problems. The validity of that design, of course, hinges on the assumption that the respondents would reveal corruption problems if such existed. The respondents were granted anonymity, and the results of the survey suggest that they did not hesitate to report such problems.

Overall, indications of corrupt behavior were more common than anticipated, given Sweden's international reputation as a low-corruption country. A total of 642 out of 1074 respondents in the sample analyzed $(60 \%)$ indicated that officials in their community had been offered money or other benefits, and 235 out of 1074 respondents (22\%) at least partially agreed with the statement that diverting public resources for their personal benefit was easy. The survey data thus fit well with recent evidence of corruption at the local level in Sweden's public sector (Dahlström and Sundell 2014; Wångmar 2013; Statskontoret 2012; Erlingsson et al. 2008a, b).

It bears noting that these indications of corruption problems in Sweden are not visible in the popular Corruption Perception Index (CPI) compiled by Transparency International (and similar indicators), wherein Sweden typically is ranked among the least corrupt countries in the world. The CPI is an index based mainly on experts' views of the level of corruption in different countries, and it has met widespread criticism. For example, it has 
been argued that the CPI and other cross-national corruption indices are poor proxies for the actual level of corruption (Razafindrakoto and Roubaud 2006; Heywood and Rose 2014), and that they tend to focus too much on bribes in relation to other forms of corruption, making them ill-suited for capturing corruption in established democracies with highly developed economies (Andersson 2017; Heywood 2015).

Swedish municipalities offer an interesting setting for studying political behavior because of their high levels of political autonomy and the large amounts of public resources managed at the municipality level. With an average annual budget that is similar to the US federal government's budget in per capita terms, Swedish municipalities are the main provider of child care, education, and elder care for the entire population, and they are involved heavily city planning activities, including issuing building permits. By using within-country variation, country-specific factors are held constant, and the results obtained are less prone to omitted variable bias than standard cross-country regressions (as noted by Bäck 2003).

The results presented in this paper add to the extensive literature on the determinants of corruption (Treisman 2000, 2007; Andvig and Fjeldstad 2001; Montinola and Jackman 2002; Lambsdorff 2006; Pellegrini and Gerlagh 2008; Fan et al. 2009; Goel and Nelson 2011a, b; Potrafke 2012). Treisman (2007, p. 211) summarizes that "quite strong evidence suggests that highly developed, long-established liberal democracies, with a free and widely read press, a high share of women in government, and a history of openness to trade, are perceived as less corrupt." Similarly, Andvig and Fjeldstad (2001) argue that the most robust finding in the literature is the negative correlation between corruption and economic development. They also note that some evidence has been reported that democracy reduces corruption (but probably only slowly-see Treisman 2000) and that more open economies exhibit less corruption (see also Wei 2000). Using US state-level data, Goel and Nelson (2011b) find that some results that hold, regardless of how corruption is measured: greater educational attainment in a state reduces corruption, while greater judicial employment (i.e., courts and activities associated with courts) adds to it. Consistent with the cross-country evidence, they also find that perceived corruption declines with greater economic prosperity.

Our paper also contributes to a separate literature on corruption at the individual or firm level. Persson et al. (2003) use cross-country data (such as the Corruption Perception Index and the International Country Risk Guide) to show that larger shares of candidates elected from party lists are associated with more corruption. They interpret this as an effect of less individual accountability. Using Italian data, Cingano and Pinotti (2013) find a revenue premium in politically connected firms. Similarly, Amore and Bennedsen (2013) use exogenous changes in Danish local municipality sizes to identify a large positive effect of political power on the profitability of firms related by family ties to local politicians. Their work-similarly to the results presented in this paper-suggests that having too many representatives may be socially costly. Auriol and Gary-Bobo (2012) explicitly model the number of legislative seats as determined by a tradeoff between the need to economize on decision-making costs and the democratic requirement that decisions should reflect the citizens' true preferences. Their estimates suggest that on the national level, the United States has too few representatives, while France and Italy have too many. Another closely related paper is Fan et al. (2009), who combine cross-country analysis with firm-level data to find that in countries with larger numbers of governmental or administrative tiers, and with more local public employees, reported bribery is more frequent.

The paper proceeds as follows. Section 2 contains some theoretical considerations, and Sect. 3 provides some background description of Sweden, describes the data and the 
empirical approach. The main results and some robustness checks are presented in Sects. 4 and 5 contains a concluding discussion. An online appendix contains additional findings from robustness tests.

\section{Theoretical considerations}

The most basic models of government corruption in the political economy literature (based on Shleifer and Vishny 1993) argue that governments have incentives to use their regulatory powers to extract bribes, and that too many politicians or political units will result in more corruption than a unitary government body that internalizes the effect of bribing on the incentives for firms and citizens to produce wealth. Several relevant mechanisms are described by Rowley and Schneider (2004). In essence, when citizens delegate decisionmaking authority to their elected representatives, that delegation creates a principal-agent problem: In the absence of political constraints, elected representatives may choose to use their official positions to pursue their own self-interests.

Based on the mechanisms discussed by Rowley and Schneider (2004), it can be concluded that the isolated effect of council size on such corruption problems is ambiguous theoretically. For example, voters' costs of monitoring their elected representatives are lower in larger councils when the number of constituents per representative is smaller. On the other hand, in larger councils each representative will be less influential, lowering the incentives for monitoring. Rowley and Schneider note also that a similar ambiguity holds for vote buying: Votes are cheaper in larger legislatures, but to assemble a majority coalition, more of them must be bought.

In the context of Swedish municipalities, Pettersson-Lidbom (2012) argues that increasing the number of legislators may lead to better monitoring and control of the public administration, but this is true only if council members are able to coordinate their monitoring efforts. In all, no clear theoretical prediction exists regarding how larger councils should affect corruption problems, and the issue must be examined empirically.

\section{Background, data and empirical approach}

\subsection{Swedish municipalities}

The current structure on Swedish municipalities can be traced back to a process of change that started in 1952, and ended with massive municipal amalgamations completed in 1974. Between those years, Sweden's population increased from 7.2 million to 8.2 million, but the number of municipalities fell from 2498 to 278; the number of elected local representatives fell likewise by 200,000 (Erlingsson et al. 2010). The stated reason underlying these changes was to increase the efficiency of local service provision. Naturally, concerns also were expressed that such efficiency would come at the cost of less democratic participation (Nielsen 2003; Wollmann 2004). The average size of Swedish municipal councils reached a maximum in 1988 (47.85 seats on average) and has been falling steadily since then to 44.1 seats today (after the 2014 election).

Because some municipalities have been split, Sweden currently is (and was at the time of the survey) divided administratively into 290 municipalities and 20 regions. Accounting for $62 \%$ of public employment in Sweden in 2014, municipalities are the nation's largest 
administrative units both politically and economically. Financed mainly by a proportional income tax of approximately 20\%, municipalities are responsible for the provision of schooling, child care, and elder care, leaving only the provision of social insurance, higher education, and defense to the central government. Municipalities also handle welfare provision, zoning issues (including building permits and permission to sell alcohol), culture, and public transport.

Total public municipality consumption accounts for $20 \%$ of national GDP, compared to $7 \%$ of GDP for the central government. With an average population of 30,000, the mean annual municipality budget is USD 217 million. Roughly three-quarters of this amount is spent on child care, primary and secondary education, and care for the elderly.

Each municipality has its own council (kommunfullmäktige), responsible for all municipal activities. They do not, however, pass legislation. Members of the local council are elected on party lists and meet approximately once a month. Local councils are elected (together with regional and central elections) every four years (before 1994, every three years).

\subsection{Corruption in Swedish municipalities}

To measure the prevalence of corruption problems in Swedish municipalities, Erlingsson et al. (2008a, b) conducted a detailed anonymous web-based survey of local top politicians and high-ranking civil servants in 2008. The survey was developed in 2007 in collaboration with several Swedish corruption experts, relying on both direct and indirect reports of corruption as well as anecdotal vignettes. For the survey, the top four politicians (the chair of the executive board, the vice chair of the executive board, the chair of the municipal council and the chair of the municipal audit department), along with the top three civil servants (the municipal manager, the budget manager and the staff manager) in each of the 290 municipalities, were identified and invited to participate in an anonymous online survey. While the politicians surveyed typically are part of the local councils, the civil servants are not political appointees. The total survey population comprised 2024 individuals, and 1184 (58\%) of them completed the survey. Among the 35 questions asked in the survey, six dealt directly with corruption problems. These questions are shown in Table 1, and they all are used in constructing our index of corruption problems (results using the six questions separately are presented in the appendix).

The decision to let the respondents be anonymous was made in order to improve the response rate and the quality of the answers. The drawback is that we do not know who has responded to the survey. Still, by studying the survey responses, we can gain some information about the character of the nonresponses. The dataset includes responses from 287 out of 290 municipalities, and for 247 municipalities we have responses from both politicians and civil servants. The response rate does not have any clear geographical pattern, and no substantial differences are evident depending on the size of the municipalities (geographically or in terms of number of inhabitants). If we compare the response rate by types of municipalities, using the classification of Swedish municipalities that the Swedish Association of Local Authorities and Regions has constructed based on structural parameters such as population, commuting patterns, and economic structure, we find that the response rates vary between 52 and $62 \%$. Furthermore, if we compare the two main groups of respondents, we find that propensities to fill out the questionnaire are about the same- $59 \%$ among politicians and $57 \%$ among civil servants. The difference in response rate by gender is only about one percentage point. Thus, the data we have do not indicate any severe problems related to nonresponse bias. 
Table 1 Questions on corruption problems

Survey question

1. How often are you, in your position as elected representative or in your duty, offered money or other benefits in order to make a decision in favor of the person/persons offering the benefit?

2. How often do you think other politicians and civil servants in your municipality are offered money or other benefits in order to make a decision in favor of the person/persons offering the benefit?

3. How often do you think other politicians and civil servants in your municipality have actually accepted the benefit offered to them?

4. How often have you been subject to violence, threat of violence, or blackmail, where the person exposing you has demanded that you, in your municipal duty/service, act in a way that you would otherwise have not?

5. In my municipality, the public procurement process is impartial.

6. If I wanted to, it would be easy for me to bring benefits to me or my close ones, at the expense of the municipality

Questions have been translated from Swedish by the authors

All questions offered multiple response categories, ranging from "never" to "very often" (questions 1-4) and from "strongly agree" to "strongly disagree" (questions 5 and 6). Figure 1 shows the share of respondents reporting inappropriate behaviors, as well as the share of respondents not answering for each of the six questions in Table 1. Response rates were highest for the first question, which inquired directly about personal experiences; most respondents appeared to reject indications of personal involvement without much hesitation. Response rates were lowest for reports on others having accepted bribes. With respect to actual evidence of corrupt behavior, a remarkable $59.8 \%$ of all respondents indicated that others in their community had been offered bribes while in office, and more than half $(51 \%)$ of respondents indicated that bribes had been accepted. A total of $41.4 \%$

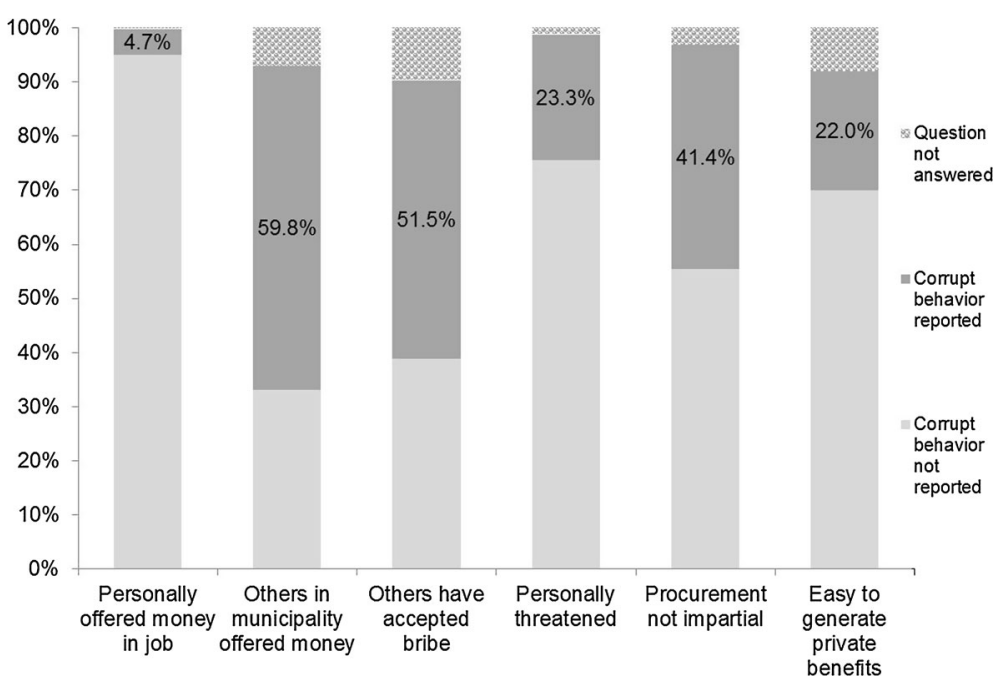

Fig. 1 Corrupt behavior questions: response rate and fraction reporting corrupt behavior 
suggest that the letting of procurement contracts is not impartial, and $23.3 \%$ reported having been threatened during their official duties.

In our baseline analysis, we aggregated the answers into a single measure of corruption using principal component analysis (PCA). The first principal component accounted for $35 \%$ of the total variation, with the highest factor loadings on questions 2 and 3 , where respondents reported on other politicians being offered or having accepted bribes. We normalized the PCA score into a $\mathrm{z}$-score variable with mean 0 and standard deviation 1 . As a robustness test, reported in the appendix, we also created and tested alternative indices without substantial changes in the results.

Corruption reports varied both within and across municipalities, with community-level variation accounting for approximately $25 \%$ of the total variation in reported corruption. The substantial variation in reporting across individuals may be interpreted as differences in subjective experiences, but may also reflect heterogeneity in reporting. To use the provided information most efficiently, we relied on individual reports (aggregated into individual-level summary scores) in our main empirical specification. As robustness checks reported in the appendix, we show results for specifications where survey answers were aggregated at the municipal level, and where answers to the six questions were analyzed item by item.

\subsection{Other municipality data}

Data on municipal characteristics were combined from a variety of sources. Population size and age structure data were collected by Statistics Sweden and compiled by Johansson (2006). We also compiled information on geographical area, number of council seats, percentage of population with some college education, "close" recent election results and whether the same party had been in power since 1995 from the same data source (Johansson 2006). The reference year for education was 2003; "some college education" was defined as the fraction of the population 25-to-64 years of age with at least 3 years of postsecondary education. The reference year for election outcomes was 2006. We defined elections as "close" if the difference between the two major voting blocs (the four rightwing parties and the three leftwing parties) was less than five percentage points.

We also entered in our models the total municipality budget and total municipality income. The former refers to the expenditures of the municipality and is based on Statistics Sweden's collection of annual municipality accounts. Municipality income is the regional gross domestic product (GDPR) in 2008, calculated by Statistics Sweden, divided by the population of the municipality.

To control for politicians' genders, we included a variable that measured the share of women among all local politicians in 2007. The information came from Statistics Sweden's survey of elected representatives in municipalities and county councils.

We used information on the number of local newspaper offices in the municipalities to capture media coverage of local politics. That information was compiled by Bergh et al. (2013). Furthermore, we also used Statistics Sweden's information on shares of foreignborn and shares of urban population within the municipalities. Urban population was defined as the share of population that resided in the city center. Finally, the variable "major city" was defined as one of the three largest Swedish municipalities, i.e., Stockholm, Gothenburg and Malmö. 


\subsection{Empirical model}

The main empirical model we estimate is

$$
c_{i j}=\alpha+\beta_{1} \text { Seats }_{j}+X_{j} \gamma+R_{i} \phi+\delta_{r}+\varepsilon_{i j},
$$

where $C_{i j}$ is the (normalized) corruption score of government official $i$ in municipality $j$, Seats is the number of council seats, $X_{j}$ and $R_{i}$ are vectors of municipality and respondent characteristics, and $\delta_{r}$ are regional fixed effects. At the municipality level, we control for total spending, population size (linear and quadratic), the share of population of working age and retirement age (20-64 and 65 and older), municipality income, area (thousands of square $\mathrm{km}$ ), the share of adults with at least a college education as proxy for the average human capital in each municipality, urban population share, and foreign population share. We also control for factors that have been found to affect corruption in previous studies: the share of women in local elected politicians (Swamy et al. 2001), the number of local newspaper offices (Gentzkow et al. 2004) and local political competition (Shleifer and Vishny 1993).

Though we do not aim to uncover a causal effect of public spending on corruption, we control for public spending because Pettersson-Lidbom (2012) finds that municipalities with larger local councils tend to have smaller public expenditures, which may influence corruption. At the respondent level, we include the following variables collected as part of the corruption survey: sex, type of appointment (politician or bureaucrat) and educational attainment. Because those who are new in local politics are less likely to have experienced corruption problems, we also control for the duration of current appointment.

\subsection{Identification strategy}

To overcome endogeneity concerns, we make use of the fact that Swedish law Коттиnallagen has constitutional status and stipulates a minimum number of seats for each local council depending on the number of eligible voters residing in the municipality on March 1 the year before the election year. The purpose of the rule is to ensure a high level of proportionality and representation of minority populations. Electoral rolls are produced based on a national population register, which is updated daily. Voter cards are sent to all entitled to vote, and no registration is necessary. The minimum number of seats per municipality is fixed for a term. The required council sizes have been constant since 1979, and are summarized in Table 2.

Municipalities are allowed to increase the number of seats above the minimum requirement, and several have chosen to do so in the past. Given that the law is tied in a non-linear way to population, the law is in practice most relevant when municipalities

Table 2 Constitutional minimum council seat requirements

\begin{tabular}{lcc}
\hline \multicolumn{2}{l}{ Number of eligible voters } & \multicolumn{2}{c}{ Minimum number of seats } \\
\hline From & To & \\
\hline 0 & 12,000 & 31 \\
12,001 & 24,000 & 41 \\
24,001 & 36,000 & 51 \\
36,001 & 100,000 & 61 \\
Stockholm & & 101 \\
\hline
\end{tabular}


grow in population, and must increase their council size when passing a threshold. Figure 2 shows the minimum as well as the actual number of seats at the municipality level. It is clear that the law is being followed, and it is noted that the requirements are exceeded by a large number of municipalities (59\% overall), while $41 \%$ of municipalities currently have exactly the number of seats legally required.

Table 3 shows descriptive statistics for all variables used in the analysis.

\section{Results}

Basic OLS results are reported in Table 4. In column 1, we show the relation between corruption and council size conditional on total expenditure, municipality population and income, newspaper presence, and electoral competition. In column 2, we add controls for municipality characteristics; in column 3, we add respondent characteristics, and in column 4, we add regional dummies. Overall, the positive effect of seats is stable, and statistically significant across all specifications. The estimated coefficient is relatively small in magnitude, implying that a 10-seat increase (which typically is required when a threshold is passed) increases corruption by about 0.15 standard deviations. Corruption increases strongly with population size, while income per capita has the expected negative sign, but is not significant.

Among the control variables, it is worth noting that having no change in the ruling party in the recent past is associated with a small reduction in corruption. This effect could be generated by respondents systematically reporting more corruption in more contested areas. We find no effect of media presence, and among the municipality controls not shown, no effect is found for female politician share-in contrast to Dollar et al. (2001). Finally, it is worth noting that total government expenditure is negatively associated with corruption, and increasingly so when more controls are added. While this cannot be interpreted as a causal effect, the negative sign is still surprising if one expects public expenditures to cause corruption.

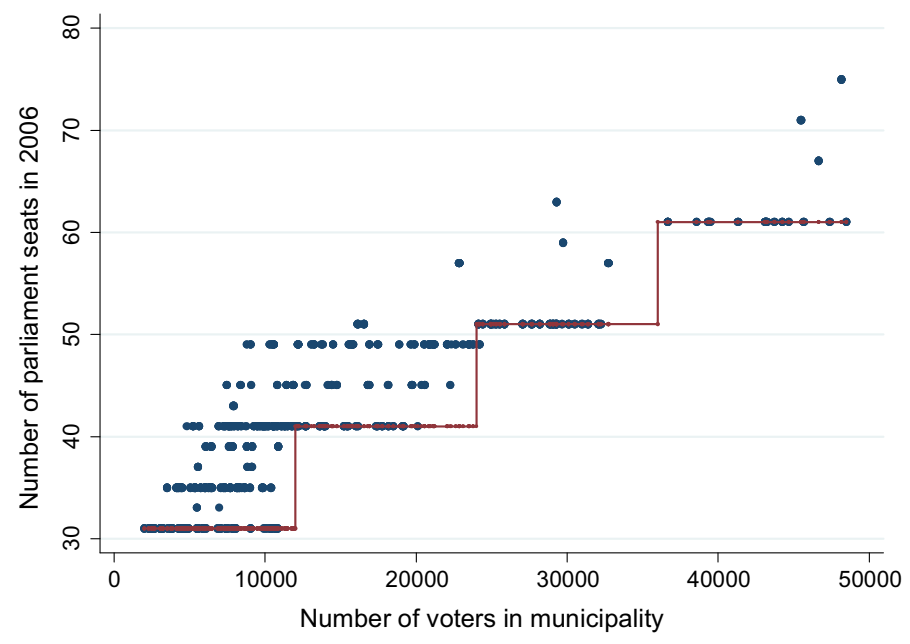

Fig. 2 Actual and minimum number of seats in local councils 2007 
Table 3 Descriptive statistics

\begin{tabular}{lrrll}
\hline Variable & Mean & Standard deviation & Min & Max \\
\hline Municipality characteristics & & & & \\
Area ('000 square km) & 1.39 & 2.39 & 0.009 & 19.37 \\
Close recent election (<5\% point gap) & 0.14 & 0.35 & 0 & 1 \\
Female politicians share & 41.28 & 4.30 & 24.4 & 52.4 \\
Foreign population share 2010 (\%) & 10.84 & 5.32 & 4.05 & 39.75 \\
Major city & 0.01 & 0.11 & 0 & 1 \\
Municipality income 2008 (US\$ '000s) & 40.33 & 17.58 & 17.25 & 174.58 \\
Municipality council seats 2006 & 45.70 & 12.08 & 31 & 101 \\
Number of local newspaper offices in municipality & 1.20 & 0.92 & 0 & 4 \\
Percentage of adults with some college education & 12.23 & 6.03 & 5 & 48 \\
Population size (10,000) & 3.27 & 6.45 & 0.26 & 77.12 \\
Same party in power since 1995 & 0.46 & 0.50 & 0 & 1 \\
Share of population age 65 and older & 19.36 & 3.62 & 9.40 & 28.90 \\
Share of population age 80 and older & 5.90 & 1.40 & 1.89 & 9.89 \\
Total budget 2004 (US\$ 100 millions) & 2.17 & 4.61 & 0.21 & 57.13 \\
Urban population share 2010 (\%) & 74.65 & 14.56 & 31 & 100 \\
Working age share (20-64) & 56.24 & 2.51 & 48.20 & 65.80 \\
Respondent characteristics & & & & \\
Female & 0.30 & 0.46 & 0 & 1 \\
Bureaucrat & 0.42 & 0.49 & 0 & 1 \\
Secondary education & 0.19 & 0.39 & 0 & 1 \\
Tertiary education & 0.70 & 0.46 & 0 & 1 \\
In office for 2-10 years & 0.44 & 0.50 & 0 & 1 \\
In office >10 years & 0.29 & 0.45 & & \\
\hline & & & 0 & \\
\end{tabular}

\subsection{Instrumental variable estimation}

Given the cross-sectional nature of the data used in Table 4, we cannot rule out that the positive conditional associations observed are at least partially the result of unobserved confounders, or that that the number of seats may respond to perceived corruption (simultaneity bias). To address these concerns, we report two-stage-least squares (instrumental variable-IV) estimates in Table 5. As discussed above, the instrument used is the required number of seats. The main logic of the IV approach is to use variation in the exposure (council size in this case) driven by an exogenous variable (the instrument). As long as the instrument predicts the independent variable of interest but is orthogonal to the residual of the main equation, IV estimation will yield unbiased estimates of the causal effect of interest. As a first step, we examine the predictive power of the instrument, i.e., assess whether the constitutionally required number of seats predicts the actual number of seats conditional on a full set of control variables. This is indeed the case: in all specifications, the F-statistics for the instrument range between 80 and 118. In column 1, we control for the main variables of interest only, and gradually add a larger set of controls in columns $2-4$. The overall results remain very similar to OLS, with a small increase in the 
Table 4 OLS results

\begin{tabular}{lllll}
\hline Dependent variable & \multicolumn{4}{l}{ Corruption principal component z-score } \\
\cline { 2 - 5 } & $(1)$ & $(2)$ & $(3)$ & $(4)$ \\
\hline Number of council seats & $0.0127^{* *}$ & $0.0191^{* * *}$ & $0.0193^{* * *}$ & $0.0168^{* * *}$ \\
& $(0.00530)$ & $(0.00667)$ & $(0.00670)$ & $(0.00635)$ \\
Total government & $-0.306^{*}(0.157)$ & $-0.422^{* *}$ & $-0.440^{* *}$ & $-0.631^{* *}$ \\
expenditure 2007 & & $(0.181)$ & $(0.189)$ & $(0.275)$ \\
Population size (millions) & $17.17^{*}(9.631)$ & $21.83^{* *}(10.92)$ & $23.04 * *(11.40)$ & $36.49^{* *}(16.85)$ \\
Population size squared & $7.737^{* *}(3.298)$ & $10.61^{* * *}$ & $10.92^{* * *}(3.846)$ & $12.63^{* * *}$ \\
& & $(3.709)$ & & $(4.794)$ \\
Municipality income & -0.000197 & -0.00101 & -0.000978 & 0.000603 \\
& $(0.00217)$ & $(0.00239)$ & $(0.00242)$ & $(0.00257)$ \\
Same party in power since & $-0.139^{* *}$ & $-0.146^{* *}$ & $-0.169^{* *}$ & $-0.176^{* *}$ \\
1995 & $(0.0637)$ & $(0.0710)$ & $(0.0730)$ & $(0.0722)$ \\
Number of newspaper & $0.0167(0.0362)$ & 0.00873 & $0.00950(0.0382)$ & -0.0110 \\
offices & & $(0.0385)$ & & $(0.0452)$ \\
Municipality controls & No & Yes & Yes & Yes \\
Respondent controls & No & No & Yes & Yes \\
Region fixed effects & No & No & No & Yes \\
Observations & 1074 & 1074 & 1074 & 1074 \\
R-squared & 0.029 & 0.036 & 0.045 & 0.061 \\
\hline
\end{tabular}

$* * * p$ value $<0.01$; ** $p$ value $<0.05$; $* p$ value $<0.1$. Standard errors are clustered at the municipality level. Municipality controls included in addition to population and income are population share 20-64, population share 65 and older, municipality land area, share of population with higher education, indicator for big cities, foreign population share, urban population share, and female politician share. Respondent controls included are sex, an indicator for bureaucrat (as opposed to politician), educational attainment dummies, and tenure length group (2-10 years, $>10$ years in office)

estimated impact of additional seats. Our most tightly controlled model (Table 6, column 4) suggests that a 10 -seat increase leads to 0.26 standard deviation increase in corruption. The slightly larger effect ( 0.26 standard deviations versus 0.17 in OLS) suggests that the OLS estimate is biased downwards. A possible mechanism is that less corrupt municipalities opt for larger councils. Another plausible explanation is that the exogenous shifts in council size generated by the law (essentially forcing government size to increase from 30 to 40 , or from 40 to 50 members) generates more corruption than a gradual increase in council size observed outside of the minimum requirement. As such, the estimated IV coefficients should be interpreted as a local average treatment effect for legally required increases in council size, which may not apply to more gradual increases in council size. We explore this aspect in greater detail in the following section, where we show estimates based on a regression discontinuity design.

\subsection{Regression discontinuity design}

As an alternative identification strategy, the discontinuities in the required number of seats can be used to estimate the effect of council size on corruption using a regression discontinuity design (RDD). For RDDs to yield statistically meaningful estimates, a 
Table 5 IV estimation main results

\begin{tabular}{|c|c|c|c|c|}
\hline \multirow[t]{2}{*}{ Dependent variable } & \multicolumn{4}{|c|}{ Corruption principal component z-score } \\
\hline & $(1)$ & (2) & (3) & (4) \\
\hline Number of council seats & $\begin{array}{l}0.0139 * \\
\quad(0.00714)\end{array}$ & $\begin{array}{l}0.0276 * * \\
\quad(0.0112)\end{array}$ & $\begin{array}{l}0.0281 * * \\
(0.0111)\end{array}$ & $\begin{array}{l}0.0264 * * \\
(0.0110)\end{array}$ \\
\hline $\begin{array}{l}\text { Total government } \\
\text { expenditure } 2007\end{array}$ & $\begin{array}{c}-0.307 * * \\
(0.155)\end{array}$ & $\begin{array}{c}-0.452 * * \\
(0.179)\end{array}$ & $\begin{array}{c}-0.471 * * \\
(0.187)\end{array}$ & $\begin{array}{c}-0.662 * * \\
(0.273)\end{array}$ \\
\hline Population size (millions) & $16.88 *(9.463)$ & $20.37 * *(10.27)$ & $21.52 * *(10.70)$ & $34.62 * *(16.50)$ \\
\hline Population size squared & $8.158 * *(3.636)$ & $\begin{array}{r}13.61 * * * \\
(4.928)\end{array}$ & $\begin{array}{r}14.03 * * * \\
(5.014)\end{array}$ & $\begin{array}{r}16.02 * * * \\
(5.683)\end{array}$ \\
\hline Municipality income & $\begin{array}{r}-0.000218 \\
(0.00217)\end{array}$ & $\begin{array}{r}-0.00131 \\
(0.00247)\end{array}$ & $\begin{array}{r}-0.00128 \\
(0.00249)\end{array}$ & $\begin{array}{l}0.000433 \\
\quad(0.00258)\end{array}$ \\
\hline $\begin{array}{l}\text { Same party in power since } \\
1995\end{array}$ & $\begin{array}{r}-0.138^{* *} * \\
(0.0635)\end{array}$ & $\begin{array}{r}-0.146^{* *} \\
(0.0711)\end{array}$ & $\begin{array}{r}-0.168 * * \\
(0.0729)\end{array}$ & $\begin{array}{r}-0.178 * * \\
(0.0713)\end{array}$ \\
\hline Number of news outlets & $0.0144(0.0389)$ & $\begin{array}{r}-0.00674 \\
(0.0439)\end{array}$ & $\begin{array}{r}-0.00654 \\
(0.0435)\end{array}$ & $\begin{array}{r}-0.0242 \\
(0.0468)\end{array}$ \\
\hline Municipality controls & No & Yes & Yes & Yes \\
\hline Respondent controls & No & No & Yes & Yes \\
\hline Region fixed effects & No & No & No & Yes \\
\hline Cragg-Donald F-stat & 943.8 & 427.6 & 424.4 & 445 \\
\hline Observations & 1074 & 1074 & 1074 & 1074 \\
\hline R-squared & 0.029 & 0.034 & 0.043 & 0.059 \\
\hline First stage F-stat & 80.08 & 100.2 & 98.99 & 117.9 \\
\hline
\end{tabular}

$* * * p$ value $<0.01$; ** $p$ value $<0.05$; * $p$ value $<0.1$. Standard errors are clustered at the municipality level. Municipality controls included in addition to population and income are population share 20-64, population share 65 and older, municipality land area, share of population with higher education, indicator for big cities, foreign population share, female politician share, and urban population share. Respondent controls included are sex, an indicator for bureaucrat (as opposed to politician), educational attainment dummies, and tenure length group (2-10 years, $>10$ years in office)

sufficiently dense distribution of outcomes around the cutoff is needed. As illustrated in Fig. 3, the majority of Swedish municipalities have less than 25,000 voters, and the most suitable cutoff for an RDD design is the increase in the required number of seats at 12,000 voters. Table 6 compares average municipality and politician characteristics around that cutoff. Using a population band of 3000 voters on either side of the cutoff, there are 176 records just below the cutoff and 80 observations just above the cutoff, and these observations do not differ with respect to any of the variables available. ${ }^{1}$

One of the most critical assumptions underlying the RDD design is that the assignment variable cannot be modified by subjects. In this case, it is worth emphasizing that municipalities are not involved in the process of deciding where eligible voters vote and that no one has to register in order to be able to vote. Statistics on the number of eligible voters are produced by the Swedish Election Authority, based on the national population register, which is updated daily. To confirm that there is no "gaming" around the 12,000voter cutoff, we plot population densities in Fig. 3. If politicians or other stakeholders were

${ }^{1}$ Unfortunately, the cutoff at 12,000 voters is the only one with a sufficiently large number of municipalities close to the cutoff. As a result, we cannot say if the effect of additional seats on corruption is linear or not. 
Table 6 Balance around the 12,000-voter cutoff

\begin{tabular}{|c|c|c|c|c|c|}
\hline & \multirow{2}{*}{\multicolumn{2}{|c|}{$\frac{\text { Below cutoff }}{\mathrm{N}=176}$}} & \multicolumn{2}{|c|}{ Above cutoff } & \multirow{2}{*}{$\begin{array}{l}\text { Equal means } \\
\text { test }\end{array}$} \\
\hline & & & $\mathrm{N}=80$ & & \\
\hline \multirow[t]{2}{*}{ Voters } & \multicolumn{2}{|c|}{$\begin{array}{l}9000-11,999 \\
\text { voters }\end{array}$} & \multicolumn{2}{|c|}{$\begin{array}{l}\text { 12,000-14,999 } \\
\text { voters }\end{array}$} & $P$ value \\
\hline & Mean & SD & Mean & SD & \\
\hline Public expenditure per capita (SKR) & $45,389.7$ & 4220.5 & $45,667.4$ & 2817.4 & 0.764 \\
\hline Income per capita 2006 (US\$’000 s) & 37.2 & 14.5 & 34.6 & 6.2 & 0.339 \\
\hline Share of population age 65 and older & 55.6 & 1.4 & 56.1 & 1.8 & 0.356 \\
\hline Share of population age 80 and older & 19.8 & 3.1 & 19.0 & 3.4 & 0.474 \\
\hline Area ('000 square km) & 1.1 & 1.8 & 0.7 & 0.5 & 0.155 \\
\hline $\begin{array}{l}\text { Percentage of adults with some college } \\
\text { education }\end{array}$ & 10.1 & 3.0 & 11.2 & 4.7 & 0.336 \\
\hline Foreign population share $2010(\%)$ & 10.2 & 4.6 & 9.3 & 2.4 & 0.330 \\
\hline Urban population share $2010(\%)$ & 70.4 & 14.6 & 74.8 & 13.0 & 0.276 \\
\hline Female politicians share in council & 40.3 & 4.6 & 39.9 & 5.2 & 0.749 \\
\hline Female & 0.3 & 0.4 & 0.2 & 0.4 & 0.489 \\
\hline Bureaucrat & 0.4 & 0.5 & 0.4 & 0.5 & 0.742 \\
\hline Secondary education & 0.2 & 0.4 & 0.2 & 0.4 & 0.404 \\
\hline Tertiary education & 0.7 & 0.5 & 0.7 & 0.5 & 0.564 \\
\hline In office for $2-10$ years & 0.4 & 0.5 & 0.4 & 0.5 & 0.758 \\
\hline In office $>10$ years & 0.3 & 0.5 & 0.3 & 0.4 & 0.211 \\
\hline $\begin{array}{l}\text { Number of local newspaper offices in } \\
\text { municipality }\end{array}$ & 1.1 & 0.9 & 1.4 & 0.8 & 0.369 \\
\hline Same party in power since 1995 & 0.4 & 0.5 & 0.4 & 0.5 & 0.594 \\
\hline
\end{tabular}

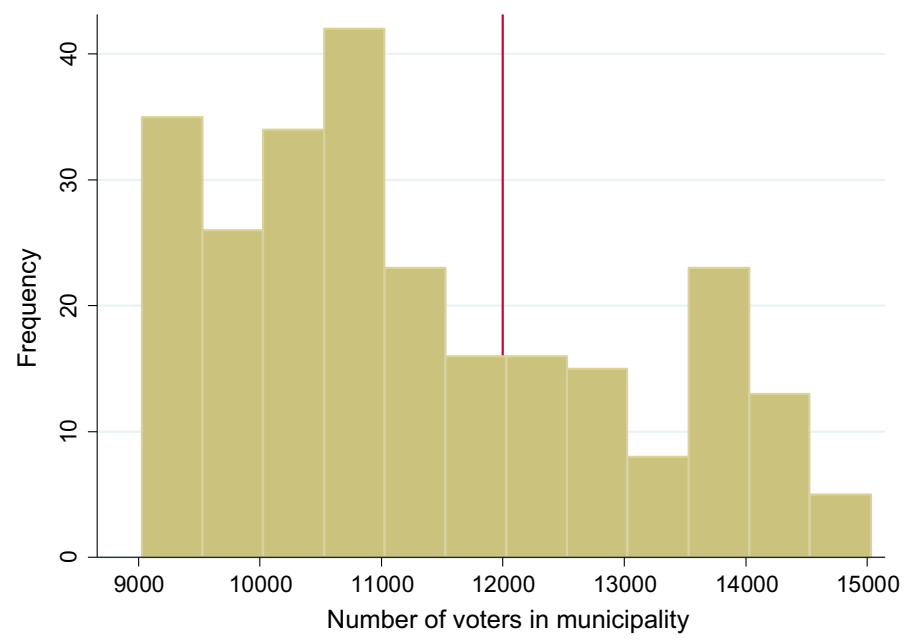

Fig. 3 The distribution of municipality voters around the 12,000-voter cutoff. Note The figure shows the number of municipalities in brackets of 500 voters for communities between 9000 and 15,000 voters 


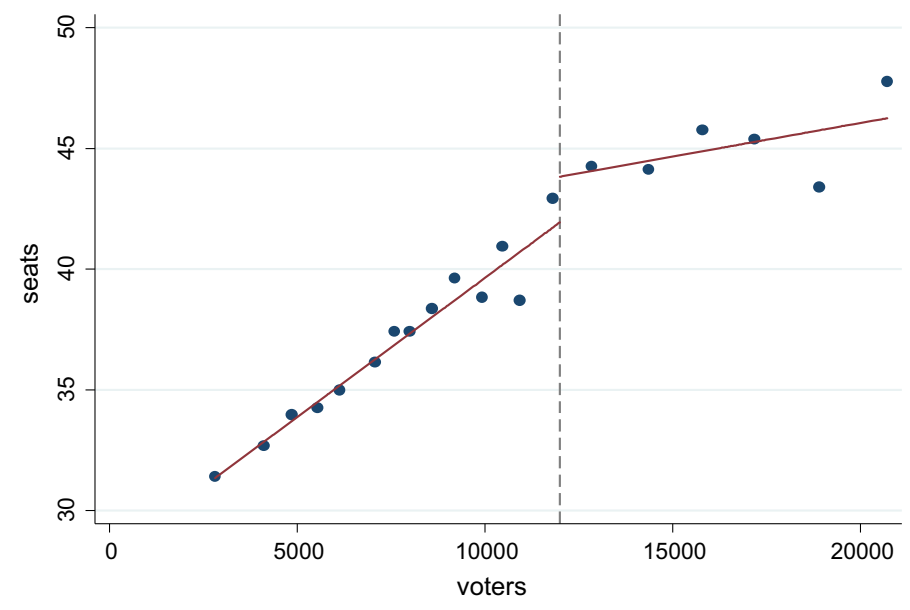

Fig. 4 Number of voters and council size

able to modify population numbers to reach specific thresholds of interest, we should see an increase in the number of municipalities with population sizes just above these specific thresholds. As Fig. 3 shows, this is not the case: the distribution of municipality sizes just above and below the threshold seems to be almost the same, which suggests that population estimates have not been modified.

Figure 4 shows the estimated increase in the number of seats around the cutoff. The number of seats increases almost linearly to the left of the cutoff and then jumps by about two additional seats. The fact that a substantial part of the jump occurs just below the cutoff suggests that many municipalities anticipate that population will increase, and increase the number of seats voluntarily.

Figure 5 shows the main regression discontinuity results for the corruption z-score. Average corruption scores are distributed fairly evenly around zero to the left of the cutoff and have a strong cluster in the 0.3 range just above the cutoff.

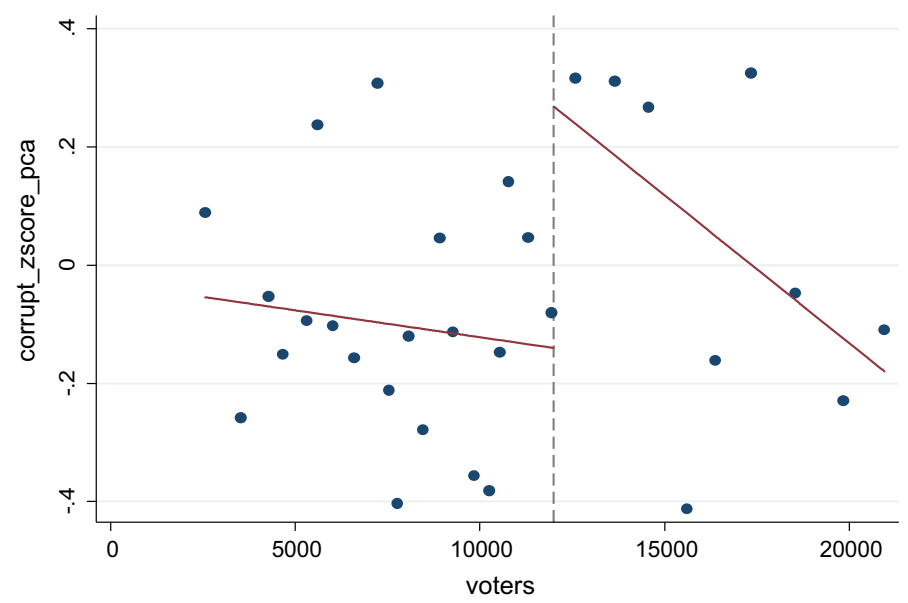

Fig. 5 Average corruption scores around the 12,000-voter cutoff 
Table 7 Regression discontinuity design estimates (cutoff 12,000)

\begin{tabular}{|c|c|c|c|c|c|c|c|}
\hline \multirow{2}{*}{$\begin{array}{l}\text { Dependent } \\
\text { variable }\end{array}$} & \multicolumn{7}{|c|}{ Corruption principal component $\mathrm{z}$-score } \\
\hline & (1) & (2) & (3) & (4) & (5) & (6) & (7) \\
\hline $\begin{array}{l}\text { 41-seat } \\
\text { requirement }\end{array}$ & $\begin{array}{r}0.409 * * * \\
(0.138)\end{array}$ & $\begin{array}{r}0.444 * * * \\
(0.149)\end{array}$ & $\begin{array}{l}0.366^{*} \\
(0.187)\end{array}$ & $\begin{array}{l}0.276 \\
\quad(0.314)\end{array}$ & $\begin{array}{r}0.403 * * * \\
(0.142)\end{array}$ & $\begin{array}{l}0.474 * * \\
(0.198)\end{array}$ & $\begin{array}{r}0.440^{* *} \\
(0.220)\end{array}$ \\
\hline $\begin{array}{l}\text { Trend } \\
\text { specification }\end{array}$ & linear & linear & linear & linear & quadratic & cubic & quartic \\
\hline $\begin{array}{l}\text { Sample min } \\
\text { voters }\end{array}$ & 2000 & 4000 & 6000 & 9000 & 2000 & 2000 & 2000 \\
\hline $\begin{array}{l}\text { Sample max } \\
\text { voters }\end{array}$ & 22,000 & 20,000 & 18,000 & 15,000 & 22,000 & 22,000 & 22,000 \\
\hline
\end{tabular}

Estimated coefficients represent the estimates shift in average corruption z-scores around the cutoff (intentto-treat)

As Fig. 5 shows, corruption outcomes are relatively noisy above the cutoff. That suggests that the RDD results are potentially sensitive to different trend specifications. Table 7 shows the results of testing different ranges and trend specifications. While the estimates fluctuate a bit-particularly when the range is expanded-the average increase in the corruption score around the cutoff appears to be about 0.4 standard deviations. Given that the average number of seats increases by about two around the cutoff, this result implies a marginal increase in corruption of about 0.2 standard deviations for each additional seat. These estimates are large compared to OLS estimates, suggesting that the exogenous shift in additional seats at this specific cutoff may trigger a substantial increase in (perceived) corruption problems in the affected municipalities.

\subsection{Additional robustness tests}

In an online appendix, we show results from several additional robustness tests that all confirm the main findings. In summary, we tried creating the corruption index using a binary coding, where each question is coded as 1 if the respondent's answer indicated any type of problem, regardless of frequency or intensity. We also constructed a categorical index where answers were translated into ordinal scales, so that "never" is coded as 0 , "very rarely" as 1, "rarely" as 2, "sometimes" as 3 and "often" as 4, and then summing the scores to create the index. Both alternative codings generated results similar to the baseline findings.

Analyzing the six questions separately reveals significant positive findings for the answers to the questions asking if others in the municipality have been offered money and whether others have accepted bribes. In contrast, respondents' views on the impartiality of public procurement clearly are not driving the results.

Our results also can be reproduced with municipality level regressions using the median and the maximum level of reported problems in each municipality as dependent variables. Intuitively, using the minimum level of reported problems, no significant results are found.

Finally, we verified that the results for seats still hold if expenditures are excluded from the model. The correlation between the number of seats in local councils and public expenditure per capita is only -0.17 , indicating that they are two different dimensions of government size, and that no bias is introduced by including them simultaneously in the regressions. 


\section{Concluding discussion}

Corruption is a well-documented social problem, associated with a multitude of undesirable social outcomes including slow economic growth (Mauro 1995; Reinikka and Svensson 2004; Méon and Sekkat 2005; Holmberg and Rothstein 2011; Johnson et al. 2011). ${ }^{2}$ This paper investigated the empirical relation between local council size and corruption, using data from a newly collected corruption survey in Sweden. While the relation between council size and corruption is ambiguous theoretically, our empirical results are clear: OLS, instrumental variable regressions and a regression discontinuity design based on discontinuities in the required number of council seats, all suggest that larger councils lead to more corruption problems.

The ongoing trend towards smaller local councils in Sweden, is thus a factor that has served to dampen corruption problems there, according to our findings. Our data do not allow us to identify the exact mechanism that explains the result, but a possible interpretation is that larger councils mean weaker incentives for monitoring elected representatives.

The findings presented are well aligned with those reported by Fan et al. (2009), who find that bribery is more frequent in countries with larger numbers of administrative tiers. They also fit well with results for US states reported by Goel and Nelson (2011b), who find that corruption increases when local public goods and services are delivered by a larger number of governmental units (holding public expenditure constant). The fact that more politicians cause corruption problems, whereas municipalities with larger public expenditure are not more corrupt, also sits well with the results in Holcombe and Boudreaux (2015), that it is the regulatory state, rather than the productive or redistributive state, that is associated with corruption.

The size of the estimated effect is modest, with 10 additional council seats increasing our corruption index by about one-quarter of a standard deviation (based on the IVestimates in Table 5). It bears emphasizing that Sweden consistently has been ranked among the least corrupt countries in the world, which means that the size of the marginal effect may well be interpreted as a lower bound internationally. Even in Sweden, more politicians seem to imply more corruption. While it may make sense from a democratic perspective not to have local councils that are too small, our results suggest that having smaller councils is an option worth considering in the fight against corruption.

Acknowledgements The authors gratefully acknowledge the helpful comments from two referees, the journal's editor, and financial support from the Swedish Research Council and Torsten Söderberg's Foundation.

Open Access This article is distributed under the terms of the Creative Commons Attribution 4.0 International License (http://creativecommons.org/licenses/by/4.0/), which permits unrestricted use, distribution, and reproduction in any medium, provided you give appropriate credit to the original author(s) and the source, provide a link to the Creative Commons license, and indicate if changes were made.

\section{References}

Aidt, T. S. (2009). Corruption, institutions, and economic development. Oxford Review of Economic Policy, 25(2), 271-291.

\footnotetext{
2 Sometimes the point is made that corruption can foster economic development by "greasing the wheels"-but Aidt (2009) concludes that the evidence supporting the "greasing-the-wheels hypothesis" is very weak.
} 
Amore, M. D., \& Bennedsen, M. (2013). The value of local political connections in a low-corruption environment. Journal of Financial Economics, 110(2), 387-402.

Andersson, S. (2017). Beyond unidimensional measurement of corruption. Public Integrity, 19(1), 58-76. doi:10.1080/10999922.2016.1200408.

Andvig, J. C., \& Fjeldstad, O.-H. (2001). Corruption: A review of contemporary research. Report R 2001:7, Chr. Michelsen Institute.

Auriol, E., \& Gary-Bobo, R. J. (2012). On the optimal number of representatives. Public Choice, 153, 419-445.

Bäck, H. (2003). Explaining and predicting coalition outcomes. conclusions from studying data on local coalitions. European Journal of Political Research, 42, 441-472.

Bergh, A., Erlingsson, G., Sjölin, M., \& Öhrvall, R. (2013). Allmän nytta eller egen vinning? En ESOrapport om korruption på svenska. Expertgruppen för studier i offentlig Ekonomi 2013:2.

Cingano, F., \& Pinotti, P. (2013). Politicians at work: The private returns and social costs of political connections. Journal of the European Economic Association, 11(2), 433-465.

Dahlström, C., \& Sundell, A. (2014). "Göteborgsandan, Korruption Och Opartiskhet I Svenska Kommuner." in Svenska Politiker: Om de folkvalda i Riksdag, Landsting och Kommun, edited by Karlsson, D., \& Gilljam, M. Quality of Government Institute (QoG), Santérus.

Dollar, D., Fisman, R., \& Gatti, R. (2001). Are women really the "fairer" sex? Corruption and women in government. Journal of Economic Behavior \& Organization, 46(4), 423-429.

Erlingsson, G. Ó., Bergh, A., \& Sjölin, M. (2008a). Public corruption in Swedish municipalities: Trouble looming on the horizon? Local Government Studies, 34, 595-608.

Erlingsson, G., Sjölin, M., Andersson, S., \& Bergh, A. (2008b). Hur korrupt är en icke-korrupt stat? Inblickar i lokala eliters subjektiva bedömningar. Arbetsrapport $\mathrm{Nr} 1$ från projektet Tillit och korruption i lokalpolitiken, Växjö universitet.

Erlingsson, G., Wångmar, E., \& Ödalen, J. (2010). “Kommunsammanläggningarna 1952-1974: Hur blev de politiskt möjliga?” Offentlig Förvaltning. Scandinavian Journal of Public Administration, 14(3-4), 3-36.

Fan, C. S., Lin, C., \& Treisman, D. (2009). Political decentralization and corruption: Evidence from around the world. Journal of Public Economics, 93(1-2), 14-34.

Fisman, R., \& Gatti, R. (2002). Decentralization and corruption: Evidence from U.S. federal transfer programs. Public Choice, 113(1-2), 25-35.

Gentzkow, M., Glaeser, E.L., \& Goldin, C. (2004). The rise of the fourth estate: How newspapers became informative and why it mattered. NBER Working Paper No. 10791.

Gerring, J., \& Thacker, S. C. (2005). Do neoliberal policies deter political corruption? International Organization, 59, 233.

Goel, R. K., \& Nelson, M. A. (1998). Corruption and government size: A disaggregated analysis. Public Choice, 97(1), 107-120.

Goel, R., \& Nelson, M. (2011a). Government fragmentation versus fiscal decentralization and corruption. Public Choice, 148(3-4), 471-490.

Goel, R., \& Nelson, M. (2011b). Measures of corruption and determinants of US corruption. Economics of Governance, 12(2), 155-176.

Heywood, P. M. (Ed.) (2015). Measuring corruption: perspectives, critiques and limits. In Routledge Handbook of Political Corruption (pp. 137-153). London: Routledge.

Heywood, P. M., \& Rose, J. (2014). "Close but no Cigar": the measurement of corruption. Journal of Public Policy, 34(3), 507-529.

Holcombe, R. G., \& Boudreaux, C. J. (2015). Regulation and corruption. Public Choice, 164(1-2), 75-85. doi:10.1007/s11127-015-0263-X.

Holmberg, S., \& Rothstein, B. (2011). Dying of Corruption. Health Economics, Policy, and Law, 6(4), 529-547.

Johansson, L. (2006). K-fakta databasen. Official Municipality Level Statistics Collected by Leif Johansson, Lunds University.

Johnson, N. D., LaFountain, C. L., \& Yamarik, S. (2011). Corruption is bad for growth (even in the United States). Public Choice, 147(3-4), 377-393.

Kotera, G., Okada, K., \& Samreth, S. (2012). Government size, democracy, and corruption: An empirical investigation. Economic Modelling, 29(6), 2340-2348.

Lambsdorff, J. G. (2006). Causes and consequences of corruption: What do we know from a cross-section of countries? In S. Rose-Ackerman (Ed.), International handbook on the economics of corruption (pp. 3-51). Cheltenham: Edward Elgar.

Mauro, P. (1995). Corruption and growth. The Quarterly Journal of Economics, 110(3), 681-712. 
Méon, P.-G., \& Sekkat, K. (2005). Does corruption grease or sand the wheels of growth? Public Choice, 122(1-2), 69-97. doi:10.1007/s11127-005-3988-0.

Montinola, G. R., \& Jackman, R. W. (2002). Sources of corruption: A cross-country study. British Journal of Political Science, 32(1), 147-170.

Nielsen, P. (2003). Kommunindelning och demokrati. Om sammanläggning och delning av kommuner i Sverige.

Pellegrini, L., \& Gerlagh, R. (2008). Causes of corruption: A survey of cross-country analyses and extended results. Economics of Governance, 9(3), 245-263.

Persson, T., Tabellini, G., \& Trebbi, F. (2003). Electoral rules and corruption. Journal of the European Economic Association, 1(4), 958-989.

Pettersson-Lidbom, P. (2012). Does the size of the legislature affect the size of government? evidence from two natural experiments. Journal of Public Economics, 96(3-4), 269-278.

Potrafke, N. (2012). Intelligence and corruption. Economics Letters, 114(1), 109-112.

Razafindrakoto, M., \& Roubaud, F. (2006). Are International Databases on Corruption Reliable? A Comparison of Expert Opinion Surveys and Household Surveys in Sub-Saharan Africa, Document de Travail, 2006-2007, Paris: Dial (Unité Mixte de Recherche IRD 225).

Reinikka, R., \& Svensson, J. (2004). Local capture: Evidence from a central government transfer program in Uganda. Quarterly Journal of Economics, 119(2), 679-706.

Rowley, C. K., \& Schneider, F. (2004). The encyclopedia of public choice. Dordrecht: Kluwer Academic Publishers.

Shleifer, A., \& Vishny, R. W. (1993). Corruption. The Quarterly Journal of Economics, 108(3), 599-617.

Statskontoret. (2012). Köpta relationer Om korruption i det kommunala Sverige. Dnr 2011/174-5.

Swamy, A., Azfar, O., Knack, S., \& Lee, Y. (2001). Gender and corruption. Journal of Development Economics, 64, 25-55.

Treisman, D. (2000). The causes of corruption: A cross-national study. Journal of Public Economics, 76(3), 399-457.

Treisman, D. (2007). What have we learned about the causes of corruption from ten years of cross-national empirical research? Annual Review of Political Science, 10(1), 211-244.

Wångmar, E. (2013). Fall av korruption, maktmissbruk och bristande tillit i svensk lokalpolitik 1963-2011. Stockholm: Santérus.

Warren, M. E. (2004). What does corruption mean in a democracy? American Journal of Political Science, $48(2), 328-343$.

Wei, S.-J. (2000). Natural openness and good government. NBER Working paper 7765.

Wollmann, H. (2004). Local government reforms in Great Britain, Sweden, Germany and France: Between multi-function and single-purpose organisations. Local Government Studies, 30(4), 639-665. doi:10. 1080/0300393042000318030. 